\title{
Uji Aktivitas Antibakteri Ekstrak Etanol Propolis Lebah Trigona (Trigona Spp) terhadap Propionibacterium acnes Penyebab Jerawat
}

\author{
Isna Wardaniati ${ }^{1)}$ Denia Pratiwi $^{2)}$ \\ 1) D III Analis Farmasi dan makanan, FKIK Universitas Abduurab \\ Jl. Riau ujung No 76 Pekanbaru Indonesia \\ email : isna.wardaniati@univrab.ac.id \\ 2) D III Analis Farmasi dan makanan, FKIK Universitas Abduurab \\ J1. Riau ujung No 76 Pekanbaru Indonesia \\ email : denia.pratiwi@univrab.ac.id
}

\begin{abstract}
Bacterial resistence is one of the global problems both in developed countries and devoloping countries. The high cases of resistence to antibiotics require the discovery of new active substances such as antibiotics agents. Therefore, to prevent the occurence of bacterial resistance to antibacterials need to be developed research in the disovery of new drugs derived from nature one of them is propolis. Propolis is a substance produced by bees to protect the nest from variety of threats, either unfavorable environmental threats or other organism attacks. One of type of bee that produces propolis is Trigona bee ( Trigona spp). The type of chemical compounds contained in propolis are very complex, among others alkaloid, flavonoid, steroid, saponin and tannin. This research is laboratory experimental study that aim to determine the antibacterial activity of ethanol extract of Trigona spp bee propolis against Propionibacterium acnes by disc diffusion methode. The concentration of ethanol extract of propolis used was $10 \%, 20 \%, 30 \%$, $40 \%$ with positif positive using clindamycin. From the result of the research, the inhibitory power of of ethanol extract of Trigona spp bee propolis with concentration 10\%, $20 \%, 30 \%$ dan $40 \%$ is 11,7 mm, 12,3 $\mathrm{mm}, 13,6 \mathrm{~mm}$ and 14, $3 \mathrm{~mm}$.
\end{abstract}

Keywords : Antibacterial, propolis, Bee, Trigona spp, propionibacterium acnes

\section{ABSTRAK}

Resistensi bakteri merupakan salah satu masalah global baik pada negara maju maupun negara berkembang. Tingginya kasus resistensi terhadap antibiotika menuntut adanya aktivitas penemuan zat aktif baru seperti agen antibiotika. Oleh sebab itu untuk mencegah terjadinya resistensi bakteri terhadap antibakteri perlu dikembangkan penelitian dalam penemuan obat baru yang berasal dari alam salah satunya propolis. Propolis merupakan zat yang dihasilkan oleh lebah untuk melindungi sarangnya dari berbagai ancaman, baik ancaman lingkungan yang tidak menguntungkan ataupun serangan organisme lain. Salah satu jenis lebah yang menghasilkan propolis adalah Lebah Trigona (Trigona spp). Jenis senyawa kimia yang terkandung dalam propolis sangat kompleks antara lain alkaloid, flavonoid, saponin, steroid dan tanin. Penelitian ini merupakan penelitian eksperimental laboratorium yang bertujuan untuk mengetahui aktivitas antibakteri dari ekstrak etanol propolis lebah Trigona spp terhadap Propionibacterium acnes dengan metode difusi cakram. Konsentrasi ekstrak etanol propolis yang digunakan adalah 10\%, 20\%, 30\%, 40\% dengan kontrol positif menggunakan antibiotik klindamisin. Dari hasil penelitian yang telah dilakukan didapatkan hasil daya hambat ekstrak etanol propolis lebah Trigona spp terhadap Propionibacterium acnes dengan konsentrasi $10 \%, 20 \%$, $30 \%$ dan $40 \%$ adalah $11,7 \mathrm{~mm}, 12,3 \mathrm{~mm}, 13,6 \mathrm{~mm}$ dan $14,3 \mathrm{~mm}$.

Kata kunci : Antibakteri, propolis, lebah, Trigona spp, propionibacterium acnes, 


\section{Pendahuluan}

Resistensi bakteri merupakan salah satu masalah global baik pada negara maju maupun negara berkembang.Tingginya kasus resistensi terhadap antibiotika menuntut adanya aktivitas penemuan zat aktif baru seperti agen antibiotika.Oleh sebab itu untuk mencegah terjadinya resistensi bakteri terhadap antibakteri perlu dikembangkan penelitian dalam penemuan obat baru yang berasal dari alam.

Komposisi kimia propolis bervariasi tergantung dari lokasi pengambilan, hal ini disebabkan ekosistem tumbuhan sebagai sumber propolis juga berbeda.Propolis mengandung bahan campuran kompleks malam, resin, balsam, minyak dan sedikit pollen.Propolis juga mengandung zat aromatik, zat wangi, dan berbagai mineral. Khasiat propolis sebagai antibakteri dapat di manfaatkan sebagai pengobatan alternatif pada wajah yang berjerawat. Propionibacterium acnes merupakan bakteri gram positif berbentuk batang dan merupakan flora normal kulit yang ikut berperan dalam pembentukan jerawat.Sedangkan jerawat adalah peradangan yang disertai dengan penyumbatan saluran kelenjar minyak kulit dan rambut (saluran pilosebasea).Apabila saluran pilosebasea tersumbat, maka minyak kulit (sebum) tidak dapat keluar dan mengumpul di dalam saluran, saluran menjadi membengkak sehingga terjadi komedo.Komedo merupakan permulaan terbentunya jerawat, baik komedo terbuka (blackhead) atau komedo tertutup (whitehead) [1] [2] [3]. Penelitian ini bertujuan untuk mengetahui aktivitas antibakteri ekstrak etanol propolis Lebah Trigona (Trigona $s p$ ) terhadap Propionibacterium acnes

\section{Tinjauan Pustaka}

\subsection{Propionibacterium acnes}

Propionibacterium acnes adalah organisme utama yang pada umumnya memberi kontribusi terhadap terjadinya jerawat. Bakteri ini tidak patogen pada kondisi normal, tapi bila terjadi perubahan kondisi kulit, maka bakteri tersebut berubah menjadi invasif. Sekresi kelenjar keringat dan kelenjar sebasea yang menghasilkan air, asam amino, urea, garam dan asam lemak merupakan sumber nutrisi bagi bakteri ini. Bakteri ini berperan pada proses kemotaktik inflamasi serta pembentukan enzim lipolitik pengubah fraksi sebum menjadi massa padat, yang menyebabkan terjadinya penyumbatan pada saluran kelenjar sebasea. Propionibacterium acnes ukurannya bervariasi dengan diameter 0,3-1,3 $\mu \mathrm{m}$ dan panjang 1-10 $\mu \mathrm{m}$, koloni kecil, berbentuk granul dan berwarna abu-abu. Merupakan bakteri gram positif tanpa spora, flagel, dan kapsul. Bakteri ini bersifat anaerob dan berbentuk batang (basil) [3]-[6].

\subsection{Lebah Triogona}

Lebah trigona (Trigona spp) merupakan lebah asli Asia yang termasuk kedalam lebah tanpa sengat.

Lebah trigona di Indonesia memiliki beberapa nama daerah, yaitu klanceng atau lonceng (Jawa), kelulut (Kalimantan), teuweul (Sunda), gala-gala (Sumatera) atau disebut lebah lilin [7] .

\subsection{Propolis}

Propolis merupakan zat yang dihasilkan oleh lebah untuk melindungi sarangnya dari berbagai ancaman, baik ancaman lingkungan yang tidak menguntungkan ataupun serangan organisme lain. Komponen utama propolis berasal dari resin atau getah berbagai tanaman yang dikumpulkan lebah. Salah satu lebah dengan kemampuan memproduksi propolis dalam jumlah besar adalah lebah trigona (Trigona $\mathrm{spp}$ ) yaitu menghasilkan propolis sebanyak $5,8 \mathrm{~kg} / \mathrm{tahun}$ [8]

\subsection{Klindamisin}

Klindamisin merupakan suatu turunan lincomycin dengan substitusi chlorine, antibiotik yang dihasilkan oleh Streptomyces linolnensis. Sekalipun strukturnya berbeda, lincomycin mirip dengan erythromycin dalam aktivitasnya. Namun, zat ini bersifat toksin dan tidak lagi digunakan [9].

\subsection{Uji Aktivitas Antibakteri}

Aktivitas atau potensi antibakteri dapat ditujukkan pada kondisi yang sesuai dengan efek daya hambat terhadap mikroorganisme.Suatu penurunan aktivitas antimikroba juga dapat menunjukkan perubahan kecil yang tidak dapat ditunjukkan oleh metode kimia sehingga pengujian secara mikrobiologi atau 
biologi biasanya merupakan standar untuk mengatasi keraguan tentang kemungkinan hilangnya aktivitas [10].

Ada dua metode umum yang dapat digunakan, yaitu penetapan dengan lempeng silinder atau cara "lempeng" dan penetapan dengan turbidimetri atau cara "tabung". Metode pertama berdasarkan difusi antibiotik dari silinder yang dipasang tegak lurus pada lapisan agar padat dalam cawan petri atau lempeng, sehingga mikroorganisme yang ditambahkan dihambat pertumbuhannya pada daerah berupa lingkaran atau "zona" di sekeliling silinder yang berisi larutan antibiotik. Metode turbidimetri berdasarkan hambatan pertumbuhan biakan mikroorganisme dalam larutan antibiotik serba sama dalam media cair yang dapat menumbuhkan mikroorganisme dengan cepat jika tidak terdapat antibiotik [11].

\section{Metode Penelitian}

\subsection{Desain Penelitian}

Penelitian ini merupakan penelitian eksperimental laboratorik untuk melihat daya hambat ekstrak etanol propolis lebah trigona (trigona spp) terhadap Propionibacterium acnes dilakukan secara in vitro menggunakan metode difusi cakram

\subsection{Sampel}

Sampel yang digunakan dalam penelitian ini adalah ekstrak etanol propolis dari lebah trigona (Trigona spp) jenis itama yang didapatkan dari peternak lebah di Jalan Karya Bakti No. 14 Kecamatan Payung Sekaki Kelurahan Air Hitam Kota Pekanbaru.

\subsection{Alat dan Bahan}

Alat yang digunakan yaitu gunting, timbangan analitik, kaca arloji, botol maserasi, spatula, gelas ukur, batang pengaduk, pipet tetes, , vial, pipet mikro, incubator anaerob, Oven, autoklaf, cawan petri. Bahan yang digunakan pada penelitian ini adalah propolis lebah Trigona (Trigona spp) jenis itama, etanol 96\%, metanol absolut, BaCl2, H2SO4, DMSO akuades, Disk kosong, Disk Klindamisin, strain Propionibacterium acnes, alumunium foil, tissue, masker, handscoon, media MHA, media NB

\subsection{Prosedur Kerja}

1. Pengambilan propolis

Propolis dipotong menjadi beberapa bagian kecil. Tiap potongan dikumpulkan dan ditimbang sebanyak 50 gram

2. Ekstraksi propolis

Ekstraksi propolis dilakukan dengan cara merendam potongan propolis mentah menggunakan etanol 96\% dengan perbandingan berat proplis mentah dan etanol $96 \%$ sebesar 1:3 (b/v) yaitu 50 gram propolis : $150 \mathrm{ml}$ etanol $96 \%$. Proses ekstraksi dengan cara perendaman dilakukan selama 3 hari dengan pengocokan setiap hari sekitar 30 menit. Pada hari ke-3, proses ekstraksi dilanjutkan dengan menggunakan alat ultrasonik bath selama \pm 30 menit. Filtrat dan ampas hasil ekstraksi dipisahkan dengan cara disaring menggunakan kertas saring Whatman No.1. Filtrat hasil ekstraksi dipipet sebanyak $\pm 2 \mathrm{ml}$ dan dimasukkan kedalam vial untuk dipekatkan pada suhu $<25^{\circ} \mathrm{C}$ selama \pm 24 jam sampai terbentuk ekstrak pekat propolis.

3. Pembuatan Media Muller Hinton Agar

Media MHA ditimbang sebanyak 3,8 g (38 gram dalam $1000 \mathrm{ml}$ akuadest) dimasukkan ke dalam erlenmeyer $250 \mathrm{ml}$, dilarutkan dalam $100 \mathrm{ml}$ akuadest, dipanaskan sampai mendidih sambil diaduk hingga terlarut secara sempurna. Lalu disterilkan di dalam autoklaf pada suhu $121^{\circ} \mathrm{C}$ selama 15 menit. Setelah cukup waktu matikan autoklaf, biarkan suhu turun, lalu keluarkan media dari autoklaf. Dinginkan sampai suhu $45-50^{\circ} \mathrm{C}$, kemudian tambahkan sebanyak $5 \mathrm{ml}$ darah kedalam media, homogenkan. Setelah itu tuangkan media ke dalam cawan petri hingga dingin. 
4. Penyiapan biakan Propionibacterium acnes

Tuangkan 1-2 ml Nutrien Borth (NB) yang sudah disterilisasikan ke dalam tabung reaksi yang telah di sterilkan, kemudian ambil bakteri yang akan disuspensi sebanayk 1 ose dan celupkan ke dalam NB tadi kemudian aduk, inkubasikan selama 18-24 jam dalam suhu $37 \mathrm{C}$.

5. Pembuatan larutan standar Mc. Farland

Larutan $\mathrm{H}_{2} \mathrm{SO}_{4} \quad 1 \%$ dipipet sebanyak $9 \mathrm{ml}$, dimasukkan ke dalam tabung reaksi.Kemudian ditambahkan larutan $\mathrm{BaCl}_{2} \cdot 2 \mathrm{H}_{2} \mathrm{O} \quad 1,175 \%$ sebanyak $1 \mathrm{ml}$. Campuran dihomogenkan hingga didapatkan larutan keruh..

6. Pembuatan suspensi bakteri uji

Bakteri uji yang digunakan diambildenganjarumose steril, lalu masukkam kedalam tabung reaksi yang telah diisi dengan $10 \mathrm{ml} \mathrm{NaCl}$ fisiologis steril dan dikocok hingga didapatkan suspensi bakteri. Kekeruhan suspensi dibandingkan dengan kekeruhan larutan Mc. Farland

7. Penyiapan media inokulum bakteri uji

Suspensi bakteri diambil dengan kapas lidi steril, kemudian dioleskan pada permukaan media hingga semua permukaan media teroleskan suspensi bakteri secara merata.

8. Pengujian Aktivitas antibakteri ekstrak etanol propolis

Disk klindamisin diambil, kemudian letakkan pada permukaan media, berikan tekanan sebagai kontrol positif. Diambil kertas disk kosong, kemudian letakkan pada permukaan media dan berikan tekanan, tetesi DMSO menggunakan mikro pipet sebagai kontrol negatif. Diambil kertas disk kosong sebanyak 4 buah, letakkan pada permukaan media dan berikan tekanan, kemudian tambahkan ekstrak etanol propolis menggunakan mikro pipet dengan konsentrasi 10\%, 20\%, 30\%, dan 40\%. Diinkubasi dalam inkubator selama 1 x24 jam pada suhu $37^{\circ} \mathrm{C}$. Diukur diameter daya hambat yang terbentuk. Dilakukan pengulangan sebanyak tiga kali..

9. Analisa Data

Zona hambat yang terbentuk diukur menggunakan jangka sorong ketelitian $0.05 \mathrm{~mm}$. Hasil penelitian akan disajikan dalam bentuk tabel dan dijelaskan secara deskriptif.

\section{Hasil Percobaan}

4.1 Hasil diameter zona hambat ekstrak etanol propolis

\begin{tabular}{|c|c|c|c|c|c|}
\hline No & Sampel & $\begin{array}{c}\text { Diameter zona } \\
\text { hambat cawan } \\
\text { petri I( mm) }\end{array}$ & $\begin{array}{c}\text { Diameter zona } \\
\text { hambat cawan } \\
\text { petri II(mm) }\end{array}$ & $\begin{array}{c}\text { Diameter zona } \\
\text { hambat cawan } \\
\text { petri III(mm) }\end{array}$ & $\begin{array}{c}\text { Rata- } \\
\text { rata(mm) }\end{array}$ \\
\hline 1 & Ekstrak etanol propolis 10\% & 10 & 13 & 12 & 11,7 \\
\hline 2 & Ekstrak etanol propolis 20\% & 12 & 13 & 12 & 12,3 \\
\hline 3 & Ekstrak etanol propolis 30\% & 14 & 13 & 14 & 14,3 \\
\hline 4 & Ekstrak etanol propolis 40 \% & 14 & 15 & 60 & 60 \\
\hline 5 & Klindamisin & 60 & 60 & & 14 \\
\hline
\end{tabular}




\subsection{Gambar zona hambat ekstrak etanol propolis}

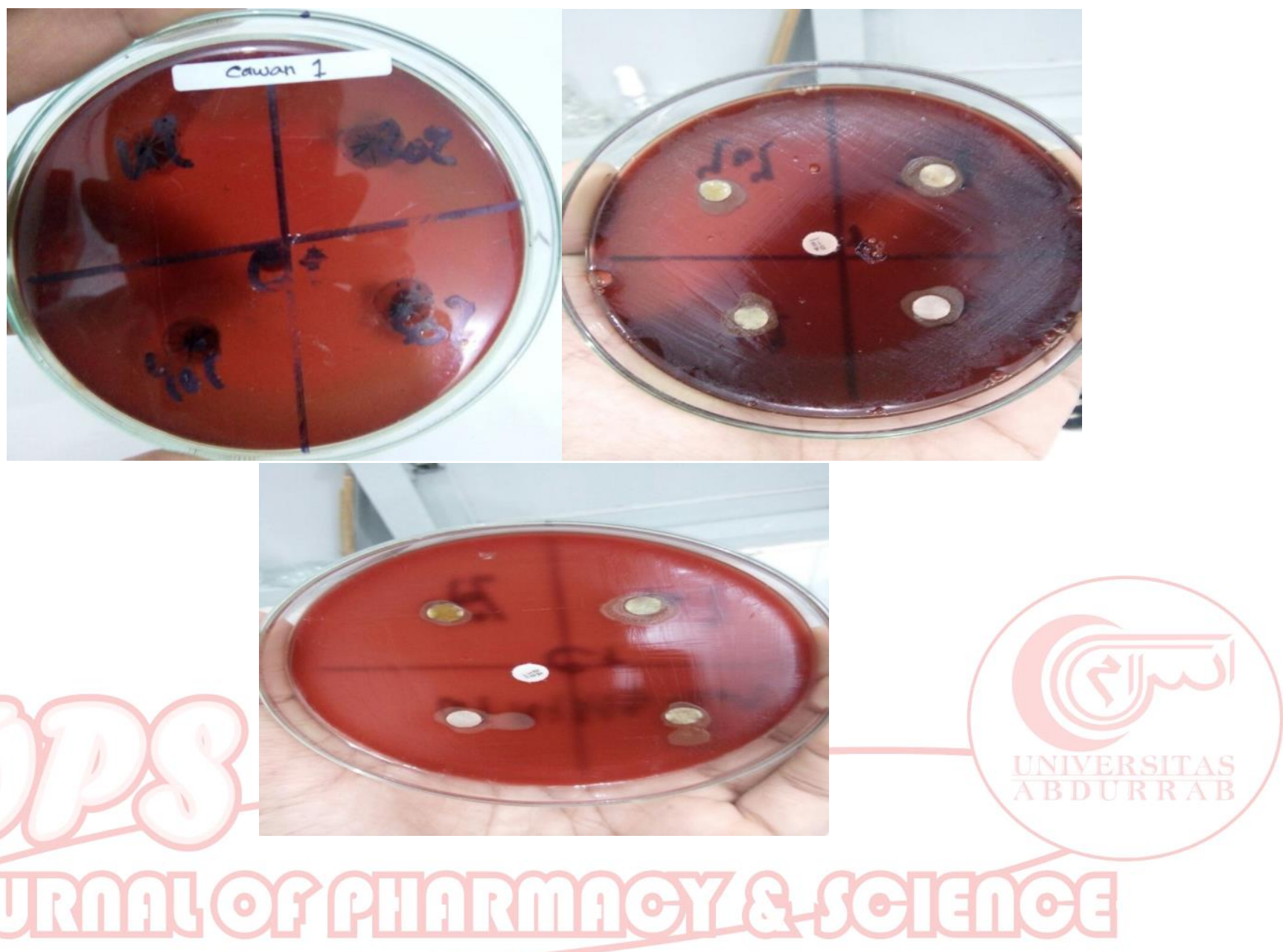

\section{Pembahasan}

Penelitian ini bertujuan untuk mengetahui daya hambat ekstrak etanol propolis dalam menghambat pertumbuhan propioni bacterium acne. Dalam penelitian ini klindamisin dipilih sebagai kontrol positif karena berdasarkan pada literatur, klindamisin adalah antibiotik pilihan untuk infeksi anaerob berat yang disebabkan oleh Bacterioides dan kuman anaerob lain yang sering terjadi pada infeksi campuran, dan baik untuk pengobatan jerawat yang parah [9]. Setelah dilakukan penelitian, uji daya hambat ekstrak etanol propolis terhadap propioni bacterium acne didapatkan hasil bahwa ekstrak etanol memiliki daya hambat terhadap pertumbuhan propioni bacterium acne, hal ini dapat dilihat adanya zona bening disekitar cakram setelah diinkubasi dalam inkubator selama 24 jam pada suhu $37^{\circ} \mathrm{C}$, karena suhu ini merupakan suhu yang baik untuk pertumbuhan bakteri. Pada konsentrasi $40 \%$ didapatkan zona hambat yang lebih besar yaitu rata-rata $14,3 \mathrm{~mm}$, sedangkan pada konsentrasi $30 \%, 20 \%$, dan $10 \%$ didapatkan zona hambat yang kecil, yaitu $13,6 \mathrm{~mm}, 12,3 \mathrm{~mm}$, dan $11,7 \mathrm{~mm}$.

\section{Kesimpulan}

Dari hasil penelitian yang didapatkan dapat disimpulkan bahwa ekstrak etanol propolis dapat menghambat pertumbuhan propioni bacterium acne, baik pada konsentrasi 10\%, 20\%, 30\% maupun 40\%. Pada konsentrasi $40 \%$ didapatkan zona hambat yang lebih besar yaitu rata-rata $14,3 \mathrm{~mm}$, sedangkan pada konsentrasi $30 \%, 20 \%$, dan 10\% didapatkan zona hambat yaitu 13,6 mm, 12,3 mm, dan 11,7 mm. 


\section{REFERENSI}

[1] T. R. Iswari and F. Latifah, "Buku pegangan ilmu pengetahuan kosmetik," Jkt. PT Gramedia Pustaka Utama, 2007.

[2] A. N. Aida, E. Suswati, and M. Misnawi, "Uji In Vitro Efek Ekstrak Etanol Biji Kakao (Theobroma cacao) sebagai Antibakteri terhadap Propionibacterium acnes (In Vitro Test of the Effect of Cocoa Beans (Theobroma cacao) Ethanolic Extract as an Antibacterial against Propionibacterium acnes)," Pustaka Kesehat., vol. 4, no. 1, pp. 127$131,2016$.

[3] T. Cahyanto, T. Sujarwo, and R. I. Lestari, "UJI AKTIVITAS ANTIBAKTERI EKSTRAK DAUN BELUNTAS (Pluchea indica (L.) LESS.) TERHADAP Propionibacterium acnes PENYEBAB JERAWAT,” J. ISTEK, vol. 9, no. 1, 2015.

[4] M. Jawetz, Adelberg's Medical Microbiology. Twenty. McGraw-Hill Companies, Inc, 2013.

[5] R. Han, H.-M. Blencke, H. Cheng, and C. Li, "The antimicrobial effect of CEN1HC-Br against Propionibacterium acnes and its therapeutic and anti-inflammatory effects on acne vulgaris," Peptides, 2017.

[6] L. W. Hosack, D. J. Overstreet, and E. S. Lederman, "In vitro susceptibility of Propionibacterium acnes to simulated intrawound vancomycin concentrations," JSES Open Access, 2017.

[7] R. A. Mahani and N. Nurjanah, "Keajaiban Propolis Trigona," Pustaka Bunda Jkt., 2011.

[8] H. C. Siregar, A. M. Fuah, and Y. Octavianty, Propolis; madu multikhasiat. Penebar Swadaya Grup, 2011.

[9] K. G. Bertram, "Farmakologi Dasar dan Klinik. Edisi 8," EGC Jkt. Pp, pp. 400-412, 2014.

[10] M. Radji, Buku Ajar Analisa Hayati edisi 3. Jakarta: Penerbit buku kedokteran EGC. Hlm, 2008.

[11] M. Radji, "Buku Ajar Mikrobiologi: Panduan mahasiswa farmasi dan kedokteran,” Jkt. Penerbit Buku Kedokt. EGC, pp. 11-19, 2011. 